\title{
O movimento "vistoria zero" e a resistência do patronato rural às políticas de assentamentos no Rio Grande do Sul
}

C'SARAUCUSTODAROS

\section{Resumo}

Neste artigo analisaremos o processo de constituição de um movimento de resistência do patronato rural às vistorias de imóveis rurais realizadas pelo Incra no estado do Rio Grande do Sul, buscando verificar os desdobramentos dessa ação na contraposição à implementação das políticas de assentamentos durante os anos de 1999 e 2002. Este movimento eclodiu em março de 1998, e foi protagonizado pelos grandes proprietários fundiários filiados ao Sindicato Rural do município de Bagé que o denominaram como "vistoria zero". Tal movimento, além de ter sido inédito, logo se irradiou pelo Estado, passando a integrar o repertório das ações de contraposição do patronato rural gaúcho à continuidade dos processos de desapropriação por interesse social para fins de reforma agrária. Argumenta-se ao longo do trabalho que o bloqueio imposto pelo patronato rural gaúcho às vistorias repercutiu diretamente numa redução drástica do número de famílias assentadas pelo Incra no quadriênio de 1999/2002, contribuindo para fortalecer ainda mais a opção do segundo governo de Fernando Henrique Cardoso pela reforma agrária de mercado.

Palavras-chave: Reforma agrária. Políticas de assentamentos. Patronato rural. Vistorias. Reforma agrária de mercado.

\footnotetext{
* Agrônomo, Doutor em Desenvolvimento, Agricultura e Sociedade pelo CPDA/UFRRJ - Professor de Extensão Rural do Departamento de Letras e Ciências Sociais da UFRRJ.
} 


\section{Introdução}

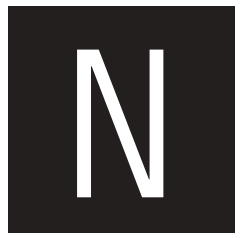

o Rio Grande do Sul, o ano de 1998 ficou marcado pela eclosão de uma manifestação até então inédita no país, no qual uma parte dos pecuaristas filiad os a uma entidade sindical patronal do município de Bagé tomou a iniciativa de barrar as vistorias de imóveis rurais que estavam sendo realizadas pelos técnicos da Superintendência Regional do Incra. Esta movimentação tomou corpo rapidamente, passando a angariar apoio dos sindicatos patronais e de outras organizações políticas de diversos municípios do Estado, constituindo-se numa das mais fortes reações do patronato rural contra a política fundiária do governo federal que vinha sendo executada para atender a demanda por terra e as ações de pressão desencadeadas pelo MST. Em face dos seus objetivos, da sua intensidade e da repercussão alcançada, seus integrantes o denominaram como "vistoria zero".

A realização de barreiras para impedir as vistorias do Incra integrouse ao já diversificado repertório de ações das organizações do patronato rural gaúcho na contraposição à luta por reforma agrária e às políticas de assentamentos no Rio Grande do Sul. 0 aspecto inovador do movimento "vistoria zero" está relacionado ao fato dos grandes proprietários fundiários gaúchos terem rompido com o seu discurso histórico de "respeito à legalidade", expresso na defesa da intocabilidade do direito de propriedade. Isto porque o impedimento das vistorias de imóveis rurais se constituiu numa ação ilegal, já que estas são reconhecidas como um procedimento rotineiro do Incra para a aferição do cumprimento da função social da propriedade fundiária, sendo garantido pela Constituição Federal de 1988 e regulamentadas pela Legislação em vigor no país.

Conforme será analisado adiante, a principal justificativa do movimento "vistoria zero" pautou-se no questionamento dos índices de lotação pecuária utilizados pelo Incra no Rio Grande do Sul, indicando que a 
"legalidade" preconizada pelas organizações do patronato rural estava diretamente relacionada à preservação do monopólio do direito da propriedade fundiária. Na medida em que a realização de vistorias pela autarquia federal sinalizou com a possibilidade de desapropriação dos imóveis que não estivessem cumprindo com a função social, a lei em vigor passou a ser abertamente desrespeitada e colocada sob questionamento pelo patronato rural. Tal fato é indicativo de que no período recente ocorreram mudanças importantes na dinâmica da luta política pelo acesso à terra, que obrigaram as entidades patronais rurais do Rio Grande do Sul a diversificarem o seu repertório de ação política.

A mudança mais significativa está relacionada ao aumento da legitimidade e da visibilidade das ações políticas em favor da realização de uma reforma agrária no país, impulsionada principalmente pela intensificação das ocupações de terras ocorrida após a constituição formal do MST no início da década de 1980 (NAVARRO, 1996; CALDART, 2000; FERNANDES, 2000). A ascensão das ocupações e da pressão social organizada por parte do MST e pelas demais organizações de representação dos trabalhadores rurais sobre as instâncias do Estado brasileiro, resultaram numa multiplicação expressiva dos assentamentos. Esse processo possibilitou a expansão territorial desses núcleos sobre diversas regiões do país, nas quais originariamente predominavam grandes latifúndios improdutivos. Em alguns casos, foi possível constatar inclusive, a formação de "manchas de assentamentos", cujos impactos sócio-econômicos vêm sendo analisados pela literatura especializada (H EREDIA et al, 2002; LEITE etal, 2004).

Entretanto, cabe advertir que este aumento da legitimidade das ações políticas em favor da reforma agrária não foi suficiente para constituir um processo político mais amplo, capaz de imprimir mudanças profundas na estrutura fundiária brasileira. ${ }^{1}$ Tal constatação não é utilizada aqui no sentido

1 Apesar dos efeitos positivos produzidos pelas políticas de assentamentos, é preciso destacar que estas não têm ocorrido numa escala capaz de produzir impactos significativos na redução da concentração fundiária do país. Vale registrar que as estimativas do índice de Gini, obtidas a partir dos dados dos Censos Agropecuários do IBGE, têm permanecido estáveis desde a década de 1950. Em 1995, esse índice ainda apresentava um valor bastante alto, da ordem de 0,856 , indicando um forte grau de concentração da propriedade das terras (GASQ UES; CO NCEIÇÃO, 2000, p. 94-95). 
de minimizar o papel exercido pelas pressões dos movimentos sociais do campo sobre as instâncias do Estado brasileiro, ao contrário, pois são justamente elas que têm contribuído para manter o tema da reforma agrária na agenda política nacional, obrigando os governos (estaduais e federais) a conferirem algum tipo de tratamento político aos conflitos fundiários oriundos das ocupações. ${ }^{2}$ No Rio Grande do Sul, a conexão estabelecida entre as ocupações de terras e a implantação de assentamentos, tem levado a uma mitigação do papel exercido historicamente pelas instâncias do Estado como fiadoras e garantidoras do monopólio do direito da propriedade fundiária. Isto significa dizer que apesar do caráter tópico e pontual das ações fundiárias, observa-se que estas têm confrontando diretamente osinteresses do patronato rural, estimulando uma reação unificada por parte de seus integrantes.

Assim, diante do notório aumento da capacidade de pressão social do MST sobre os governos estaduais e federais, as organizações do patronato rural gaúcho, em particular os sindicatos rurais ligados à Farsul, deixaram de contar exclusivamente com as instâncias repressoras do Estado para coibir o avanço das ocupações de terras e a expansão dos assentamentos nas regiões de grandes latifúndios. Tal fato obrigou essas organizações a lançarem mão de estratégias de ação de defesa dos seus interesses, equiparáveis às do seu principal antagonista no estado, o MST. ${ }^{3}$ Apesar de

\footnotetext{
$2 \mathrm{Na}$ pesquisa realizada por Heredia et all $(2002$, p. 78), constatou-se que $96 \%$ dos assentamentos investigados resultaram de situações de conflito, sendo que em $89 \%$ dos casos a iniciativa do pedido de desapropriação partiu dos trabalhadores rurais e de suas organizações, em somente $10 \%$ dos casos a iniciativa partiu do Incra.

3 Entre as principais estratégias utilizadas merecem registro as seguintes: 1) os acampamentos de vigília junto às ocupações realizadas pelo MST; 2) as campanhas de sensibilização da opinião pública em defesa da propriedade e do produtor rurais, atualmente denominadas como "maio verde" em contraposição ao "abril vermelho" organizado pelo MST; 3) os movimentos de contraposição às marchas realizadas pelo MST, autodenominadas de "contramarchas"; 4) as tentativas de boicote à principal exposição agropecuária do RS, a Expointer - utilizadas pela Farsul como um instrumento de barganha política com os governos, nos momentos de intensificação das ocupações de terras; 5) e por fim, o movimento de barreiras às vistorias de imóveis rurais realizadas pelo INCRA, objeto de análise deste artigo.
} 
essas ações serem relevantes para a compreensão da luta política pelo acesso a terra no Rio grande do Sul, observa-se que ainda existem poucos trabalhos acadêmicos dedicados em estudá-las. $\mathrm{N}$ a tentativa de suprir esta lacuna, o objetivo deste artigo será o de analisar o processo de constituição do movimento "vistoria zero", buscando verificar os seus desdobramentos na contraposição à implementação das políticas de assentamentos durante os anos de 1999 e 2002.

Argumenta-se ao longo do trabalho que o bloqueio imposto pelo patronato rural gaúcho às vistorias repercutiu diretamente numa redução drástica do número de famílias assentadas pelo Incra no quadriênio de 1999/2002, contribuindo para fortalecer ainda mais a opção do segundo governo de Fernando Henrique Cardoso pela reforma agrária de mercado. $N$ a realização deste trabalho, utilizaram-se as seguintes fontes primárias: a) entrevistas semiestruturadas com dirigentes rurais e gestores públicos; b) matérias publicadas em dois jornais de grande circulação no RS; c) dados oficiais do Incra/RS. Além desta introdução, este trabalho está dividido em quatro seções. $\mathrm{N}$ a segunda seção, apresentamos algumas indicações teóricas que permitem a construção do conceito de campo dos conflitos agrários como referencial analítico das disputas políticas e simbólicas travadas entre o patronato rural e seus antagonistas. $\mathrm{N}$ a terceira seção, são pontuados os principais acontecimentos que interferiram na execução das políticas agrárias federais no RS durante os anos 1990 e que geraram uma reação por parte do patronato rural. Na quarta seção, são pontuados as razões políticas e os principais fatos que marcaram a emergência do movimento "vistoria zero" como uma estratégia de contraposição às políticas de assentamentos no RS. Ao final do artigo apresentamos uma síntese conclusiva das análises realizadas. 


\section{O campo dos conflitos agrários e as ações do patronato rural na preservação do monopólio da posse e uso da terra}

A emergência do movimento "vistoria zero", apesar do seu ineditismo enquanto ação coletiva, não deve ser interpretada como um ato isolado, episódico e contingencial, já que faz parte de um amplo e diversificado repertório de ações mobilizadas historicamente pelos integrantes do patronato rural nos momentos em que o direito à posse e uso da terra foi posto em causa ou ameaçado por seus antagonistas. ${ }^{4} \mathrm{~N}$ este sentido, a sua constituição precisa ser vislumbrada a partir de uma perspectiva mais ampla que abarque os embates travados nos diversos "campos de luta" que compõem a estrutura do espaço social, conferindo uma ênfase especial àquele que al guns autores denominaram como "campo dos conflitos agrários" (SANTOS, 1991; HEINZE, 1991; RAM OS, 1995).

O uso desse conceito está referenciado nas categorias analíticas formuladas pelo sociólogo francês Pierre Bourdieu que concebe o "espaço social" como uma representação do mundo social, nas suas várias dimensões, sendo construído a partir de princípios de "diferenciação ou distribuição". N essa proposição, os agentes ou grupos de agentes são definidos a partir das suas posições relativas neste espaço (BOU RDIEU, 2002, p. 133).

$\mathrm{Na}$ medida em que as propriedades tidas em consideração para a constituição deste espaço são propriedades "atuantes", ele pode ser en-

4 Convém destacar que a referência ao termo Patronato Rural expressa ao longo deste trabalho é equivalente a definição de Burguesia Agrária elaborada por Tavares dos Santos, que a entende como: “(...) uma fração das classes dominantes cuja especificidade é dada pela apropriação da terra (por propriedade, arrendamento ou ocupação) e pela inversão de capital no processo de trabalho agropecuário; de modo que a origem do excedente econômico de que ela se apropria - a renda capitalista da terra combinada com a mais valia do empreendimento - reside na exploração do sobretrabalho dos camponeses e/ou na mais valia dos trabalhadores assalariados. A burguesia agrária reúne distintas frações, tais como proprietários de terras (os chamados “latifundiários") e os empresários rurais, com diferentes perfis tecnológicos, atuando em diversos ramos produtivos". SANTOS, José Tavares dos. Apresentação: A construção social dos dominantes no campo. In: RAM OS, Marília Pata. O novo e o velho ruralismo no Rio Grande do Sul: um estudo sobre os integrantes da UDR. Santa Cruz do Sul: Editora UNISC, 1995. 
tendido também como um "campo de forças", onde operam um conjunto de forças objetivas que não podem ser reduzidos apenas às vontades individuais dos agentes, ou mesmo às suas interações. As propriedades atuantes que interferem na constituição do espaço social são as diferentes espécies de "poder" ou de "capital" utilizadas nos diferentes campos. ${ }^{5} \mathrm{~A}$ posição de um determinado agente no espaço social depende da posição ocupada por ele nos diferentes campos, principalmente no que se refere à distribuição dos poderes em cada um deles, sobretudo o capital econômico, o capital cultural, o capital social, e também o capital simbólico, geralmente conhecido como prestígio, reputação, fama, etc. ${ }^{6}$ (BOU RDIEU, 2002, p.134).

Nesta ótica, a delimitação de um determinado "campo" pressupõe sempre a existência de um espaço onde se manifestam relações de poder, o que implica afirmar que a sua estruturação ocorre a partir de uma distribuição desigual de capitais entre os agentes sociais que dele fazem parte. Tais capitais são mobilizados pelos agentes nas suas lutas concorrenciais em torno de interesses específicos. ${ }^{7}$ Além disso, é preciso ter presente que

5 Para Bourdieu o "capita"l pode existir no seu estado "objetivado", na forma de materiais, propriedades, ou sob a forma de "capital cultura"I, em seu estado incorporado, representando um poder sobre o produto do trabalho acumulado em épocas passadas, ou seja, o conhecimento sobre os mecanismos de produção de determinados bens. Nas palavras do próprio autor: "As espécies de capital, à maneira dos trunfos num jogo, são os poderes que definem as probabilidades de ganho num campo determinado (de fato, a cada campo ou subcampo corresponde uma espécie de capital particular, que ocorre, como poder e como coisa em jogo, neste campo)" (BOURDIEU, 2002, p. 134).

6 Embora Bourdieu procure alertar para o fato de que o espaço social não pode ser reduzido apenas ao universo do econômico, o que nos levaria a assumir um ponto de vista economicista, ressalta que há uma tendência de que a estrutura e a hierarquia existente no campo econômico se imponham na estrutura dos demais campos (BO URDIEU: 2002, p. 135).

7 A estrutura de um determinado campo pode ser compreendida tomando-se como referência dois pólos opostos: 0 dos dominantes e dos dominados. O s agentes que ocupam o primeiro pólo são justamente aqueles que possuem um maior volume de capitais, enquanto que aqueles que se situam no pólo dominado se caracterizam por possuírem um volume menor de capitais. Para consolidar a sua posição de dominância no interior do campo, os agentes buscam construir uma visão de mundo que se imponha como verdadeira, a tal ponto de se converter naquilo que 0 autor denomina de ortodoxia. De outro lado, a visão de mundo daqueles que são os dominados no campo e, que, por meio da luta concorrencial pretendem mudar de posição, aparece definida como heterodoxia (ORTIZ, 1983). 
os limites de um campo são sempre os "limites dos seus efeitos". Assim, um agente somente faz parte de um determinado campo na medida em que nele sofre os efeitos ou que nele os produz (BO URDIEU, 2002: p. 32).

Ao fazer uso das categorias analíticas de Bourdieu, o "campo dos conflitos agrários" pode ser entendido como aquele que se constitui de estruturas objetivas que são definidas pela relação diferencial de apropriação da terra, cristalizada no capital fundiário, onde estas estruturas definem um sistema de posições no espaço social. Neste campo, as lutas se travam numa primeira instância, pelas diferentes formas de apropriação e uso da terra, sendo perpassadas, também, pelas estruturas cognitivas que direcionam as lutas simbólicas pela legitimação de interesses específicos (RAMOS, 1995, p. 25).

Entre as dimensões possíveis de serem observadas nestas lutas, pelo menos duas delas merecem destaque. U ma primeira relacionada às lutas mais amplas em torno das tentativas de reformulação do direito de propriedade consagrado no Brasil desde a promulgação da Lei de Terras, em 1850, na qual se unificou sob um único título a posse e do domínio sobre as terras, limitando drasticamente a regulação pública sobre a propriedade privada fundiária, de tal modo que esta se tornou quase que absoluta (MARTINS, 1981; FO RSTER, 2003).

A análise da história brasileira permite a demarcação de alguns momentos em que a reformulação desse direito de propriedade esteve no centro das disputas nacionais, entre os quais se destacam: 1) o processo político que culminou com a revolução de 1930, quando as correntes do movimento tenentista esboçaram as primeiras críticas ao latifúndio improdutivo, reivindicando a realização de mudanças profundas na estrutura fundiária brasileira e a inserção do preceito de que a propriedade somente poderia ser garantida pelo Estado se cumprisse com a sua função social; 2) durante os anos 1950 e 1960, quando a reivindicação por reforma agrária 
tomou impulso sob a ação política do Partido Comunista do Brasil e dos movimentos camponesese, posteriormente, pelo debate ocorrido em torno das reformas de base durante o governo João Goulart; 3) durante a transição do regime militar à N ova República, quando a apresentação da proposta do Plano N acional de Reforma Agrária, em concomitância à retomada dasocupações de terras e o surgimento do MST revitalizaram o debate sobre a reforma agrária, o qual se estendeu até o final da Assembléia N acional Constituinte de 1988; 5) a partir de 1995/1996, quando a intensificação das ocupações de terras pelo país e a pressão social exercida pelos movimentos sociais do campo, em especial o M ST recolocou o tema da reforma agrária na pauta política, obrigando o governo federal a levar adiante uma política de assentamentos mais vigorosa (CAMARGO, 1986; MEDEIROS, 1994; GOMES DA SILVA, 1996; MARTINS, 2000; CARVALHO FILHO, 2001; MEDEIRO S, 2002; M EDEIROS \& LEITE, 2004; PEREIRA 2004).

Em cada um desses momentos foi possível identificar a formação de dois pólos bastante nítidos em torno dos quais se condensaram os agentes sociais do meio rural, posicionando-se de maneira distinta acerca da natureza da questão agrária nacional e estadual e das suas possíveis vinculações com os projetos de desenvolvimento em disputa. ${ }^{8} \mathrm{Grosso}$ modo, pode-se dizer que num dos pólos se situaram e ainda hoje se situam os agentes interessados na preservação da estrutura fundiária concentrada da propriedade fundiária, na forma como ela foi legada pelas gerações passadas, corroborando para a preservação do monopólio da propriedade privada da terra. Isto significa dizer que as organizações que representam politicamente os interesses do patronato rural, costumam mobilizar todos os esforços no sentido de defender a intocabilidade do direito de propriedade. Tal defesa quase sempre é acompanhada de estratégias que visam minar com a legiti-

8 Embora seja possível visualizar a formação de polaridades em relação às disputas em torno da questão agrária, isso não significa que não tenha havido cisões ou rupturas no interior de cada pólo, geralmente oriundas das diferentes interpretações sobre o tema e sobre as estratégias de luta mais viáveis a serem adotadas. 
midade das ações protagonizadas pelas organizações que lutam pela realização de uma reforma agrária no Brasil, valendo-se da desqualificação dos trabalhadores rurais e suas organizações e do uso da violência (física e simbólica) como prática de classe (BRU NO, 2005).

N um outro pólo, estão situadas as organizações que reivindicam uma "política de reforma agrária" que possibilite uma ampla distribuição da propriedade da terra às populações que não a possuem, a fim de permitir uma modificação nas suas condições de reprodução social e econômica. Neste caso, a reivindicação do "acesso à terra" aparece vinculada à defesa da ampliação e do fortalecimento das múltiplas formas familiares de produção e por políticas públicas diferenciadas que atendam à especificidade desses grupos sociais.

A segunda dimensão relativa às lutas travadas no campo dos conflitos agrários ocorre no âmbito dos direitos consagrados na Constituição Federal e na legislação agrária em vigor. Esse novo ordenamento constitucional/ legal, apesar de delimitar um campo restrito de atuação dos agentes sociais, também se constitui num espaço de luta, pois oferece margem de interpretação que pode favorecer tanto as forças empenhadas na preservação da atual estrutura agrária, quanto àquelas empenhadas em reformá-la. N este caso, vale registrar que a Carta Magna de 1988 é bastante clara ao afirmar que o direito de propriedade somente é garantido pelo Estado brasileiro mediante o cumprimento da sua função social. ${ }^{9}$

A existência deste preceito constitucional tem sido foco de uma luta permanente entre os agentes sociais favoráveis ou contrários à execução

9 Segundo o Artigo n. 186, da Constituição Federal: "A função social é cumprida quando a propriedade rural atende, simultaneamente segundo critérios e graus de exigência estabelecidos em Lei, aos seguintes requisitos: I - aproveitamento racional e adequado; II - utilização adequada dos recursos naturais disponíveis e preservação do meio ambiente; III - observância das disposições que regulam as leis de trabalho; IV - exploração que favoreça o bem-estar dos proprietários e trabalhadores" (BRASIL, 2003, p. 130). A Lei 8.629/93 estabeleceu de forma clara apenas o primeiro requisito, considerando que o "aproveitamento racional e adequado" seria cumprido na medida em que a propriedade fosse "produtiva". Nesta direção, estabeleceu critérios de mensuração da utilização da propriedade e da sua eficiência baseados respec- 
de uma política de reforma agrária ampla e massiva no país. O s primeiros, representados pelas organizações políticas dos camponeses e trabalhadores rurais sem terra ou com pouca terra, lutam pelo alargamento da função social da propriedade fundiária, destacando a necessidade de incorporar outros critérios que levem em conta além da dimensão econômica as dimensões ambiental, trabalhista e social, destacando também a necessidade de impor um limite máximo ao tamanho da propriedade fundiária. O s últimos, representados pelas organizações políticas do patronato rural e seus aliados, movimentam-se em sentido contrário, buscando manter ou restringir a regulação pública da propriedade da terra, opondo-se radicalmente à reforma agrária e às tentativas de revisão dosíndices de produtividade, ou ainda a incorporação de outros critérios para definir a função social da propriedade fundiária.

N essa situação, as possibilidades e limites para a ampliação do acesso à terra no médio e longo prazo dependem diretamente das relações de força e das lutas travadas entre os agentes sociais que participam do campo dos conflitos agrários. Acrescente-se ainda que as lutas pela preservação ou pela mudança deste direito não se resumem apenas à conquista de posições de hegemonia ou dominância no âmbito do campo político, necessitando também da sua legitimação junto aos demais campos que integram o espaço social.

Por essa razão, a definição das estratégias de luta ou mesmo das formas de ação política, não podem ser entendidas de maneira estática, visto que estas somente ganham sentido numa relação de interação/confronto entre os agentes sociais e seus aliados/opositores no campo de lutas. Tais estratégias ganham concretude mediante 0 acionamento de diferentes tipos de capitais disponíveis aos agentes de acordo com as suas res-

tivamente, no Grau de U tilização da Terra (GU ) e no Grau de Eficiência Econômica (GEE), cujo cálculo se referencia nos índices de produtividade em vigor. Nos demais requisitos, a Lei é genérica e não oferece grandes possibilidades para a ação governamental. 
pectivas posições ocupadas no espaço social e no interior do campo dos conflitos agrários. Neste caso, é notória a posição de dominância assumida pelo patronato rural e suas organizações de representação política, tendo em vista que estes dispõem de um maior volume e diversidade de capitais, o que lhes assegura um maior grau de reconhecimento e legitimidade política e social, em face aos seus opositore ${ }^{10}$ (HEINZE, 1991; RAM OS, 1995).

Sob esta ótica, é possível interpretar o movimento "vistoria zero" como uma das reações possíveis às ameaças potenciais ou reais de alteração nas posições de poder do patronato rural, cuja principal força reside no monopólio da propriedade da terra. Tais ameaças são representadas pelas ações fundiárias desencadeadas pelo Estado no sentido de responder às ações de pressão dos movimentos sociais do campo em favor da reforma agrária. Neste sentido, o movimento "vistoria zero" se constitui num momento de representação da classe, no qual os agentes situados em posições semelhantes no espaço social tendem a apresentar uma "unidade de classe", que reforça um sentido de identidade, propiciando a evocação de símbolos do passado e do presente utilizados em sua luta pela intocabilidade do direito absoluto da propriedade da terra.

\section{A política fundiária federal no quadriênio de 1995/1998 e a sua execução no Rio Grande do Sul.}

Para entendermos o processo de emergência do movimento "vistoria zero" torna-se necessário, num primeiro momento, recuperarmos al-

10 Entre esses capitais poderíamos destacar: (a) o capital econômico, representado pela propriedade da terra e pelos ativos financeiros acumulados; (b) capital cultural, representado pelo nível de escolarização e grau de acesso aos bens culturais; (c) o capital político objetivado na sua participação junto às diversas esferas do poder público e também junto às suas entidades de representação corporativas; (d) o capital social, representado pelas redes sociais nas quais os integrantes do patronato rural costumam participar (clubes sociais, associações de produtores, CTG 's, comunidades religiosas, etc.); (e) o capital pessoal, geralmente associado ao reconhecimento, reputação e ou fama acumulada junto aos demais, entre outros (HEINZE, 1991; RAM OS, 1995). 
guns antecedentes que marcaram a luta política em torno da questão agrária naquela conjuntura. No plano nacional, observa-se que no início da década de 1990 o debate sobre a necessidade de uma reforma agrária, parecia ter perdido a sua centralidade, principalmente depois das derrotas políticas acumuladas pelos embates ocorridos em torno do Plano Nacional de Reforma Agrária (PNRA), na Assembléia Nacional Constituinte (ANC) e, por último, nas eleições presidenciais de 1989, quando a candidatura de Luiz Inácio Lula da Silva (PT) apresentou um programa agrário visando assentar um milhão de famílias durante o seu mandato (M EDEIROS, 1994). A vitória eleitoral de seu oponente, Fernando Collor de M elo (PRN), não apenas frustrou essa expectativa, como colocou em marcha um processo de ajustamento estrutural da economia brasileira à economia internacional, atendendo as premissas neoliberais preconizados pelas agências multilaterais de financiamento (FIO RI, 2001). Desse modo, sob a direção dos governos de Fernando Collor de M elo, Itamar Franco (PMDB) e Fernando Henrique Cardoso (PSDB), as políticas agrárias deixaram de ser pensadas com o objetivo de promover mudanças estruturais no campo, para se subordinarem cada vez mais às novas diretrizes macroeconômicas, convertendo-se em políticas de caráter social e compensatório (CARVALHO FILHO, 2001; MEDEIRO S, 2002; PEREIRA, 2004).

Contudo, o agravamento da situação social no campo produzido principalmente pelos efeitos regressivos das medidas de ajuste estrutural e da estabilização econômica, associado a um conjunto de acontecimentos desencadeados no biênio de 1996/1997, recolocaram a questão agrária no centro do debate político nacional. Entre esses acontecimentos destacaram-se: a) a repercussão nacional e internacional dos dois massacres de trabalhadores sem-terra nos municípios de Corumbiara (RO), em agosto de 1995, e Eldorado dos Carajás (PA), em abril de 1996; b) o aumento das ocupações de terras organizadas pelo MST e por diversos sindicatos e federações ligados à Contag; c) 0 aumento dos conflitos fundiários na região do Pontal do Paranapanema, em São Paulo; d) a realização, pelo MST, da "Marcha Nacional por Emprego e Justiça”, em 1997; e) a realização de 
protestos contra o governo brasileiro no exterior por entidades de apoio ao MST (CARVALHO FILHO, 2001; M EDEIROS, 2002; PEREIRA, 2004).

Em resposta às repercussões cau sadas pelos massacres e também como forma de retomar a iniciativa política em relação às pressões dos movimentos sociais e das entidades sindicais do campo, o governo federal criou 0 M inistério Especial de Política Fundiária (MEPF), em 1996. Posteriormente, deu início a um conjunto de ações em quatro direções que incluíam: a) a aprovação de medidas legais para acelerar e baratear as desapropriações; b) a criação de expedientes legais destinados a reprimir as ocupações de terras; c) a descentralização institucional e administrativa da política agrária; d) a adoção de programas de reforma agrária orientados pelo mercado (MEDEIRO S, 2002; M EDEIROS; LEITE, 2004; PEREIRA, 2004).

No Rio Grande do Sul, os rebatimentos desses fatos políticos, bem como das diretrizes preconizadas pela política agrária federal, inseriram-se numa conjuntura específica marcada pelos seguintes acontecimentos: 1) pela crise vivida pelo setor agropecuário gaúcho; 2) pelo aumento das ocupações de terras; 3) pela eleição de um governo estadual desinteressado em adotar uma política fundiária; 4) pela nomeação de um superintendente regional do Incra favorável ao prosseguimento de uma política de assentamentos no Estado; 5) pela reação das organizações do patronato rural gaúcho contra as vistorias realizadas pelo Incra (DA ROS, 2006a, p. 306-320).

No primeiro caso, a crise do setor agropecuário estadual estava conectada às mudanças estruturais em curso na agricultura no âmbito nacional, manifestando-se através da perda de rentabilidade na agricultura e na pecuária bovina de corte, na redução da área plantada em lavouras e na concentração da produção de grãos em grandes estabelecimentos (BENETTI, 1997 e 2000). Como consequência dessa crise, houve um rebaixamento no preço das terras e um aumento das ofertas de imóveis rurais ao Incra, que passou a realizar desapropriações de forma negociada com os proprietários fundiários. ${ }^{11} \mathrm{Em}$ segundo lugar, a elevação do núme-

11 Depoimento de Jânio Guedes da Silveira (Incra/RS). 
ro de projetos de assentamentos observada neste período, estava diretamente relacionada à intensidade das ações de pressão política do MST sobre o Incra, objetivadas no aumento das ocupações de terras no Estado a partir de 1996, que em certa medida acompanharam as tendências em curso no plano nacional, conforme indicam as tabelas a seguir.

Tabela 1. O cupações de terras, acampamentos e famílias acampadas, nucleadas e contatadas por movimentos sociais no RS, entre janeiro de 1995 e dezembro de 1998.

\begin{tabular}{cccc}
\hline Ano & $\begin{array}{c}\text { Número de } \\
\text { ocupações }\end{array}$ & $\begin{array}{c}\text { Número de } \\
\text { acampamentos }\end{array}$ & $\begin{array}{c}\text { Número de famílias } \\
\text { acampadas }\end{array}$ \\
\hline 1995 & 2 & 2 & 787 \\
1996 & 5 & 6 & 1.581 \\
1997 & 4 & 6 & 695 \\
1998 & 11 & 7 & 1.298 \\
\hline Total do quadriênio & $\mathbf{2 2}$ & $\mathbf{2 1}$ & $\mathbf{4 . 3 6 1}$ \\
\hline
\end{tabular}

Fonte: MST/RS, GRA/RS.

Tabela 2. Projetos de assentamentos implantados pelo Incra no RS entre os anos de 1985 e 1998.

\begin{tabular}{|c|c|c|c|c|c|c|c|}
\hline Peńodo & Presidente & $\begin{array}{c}\text { Numero de } \\
\text { Assentamentos }\end{array}$ & (\%) & $\begin{array}{l}\text { Área total } \\
\text { em hectares }\end{array}$ & $(\%)$ & $\begin{array}{l}\text { Número } \\
\text { de famílias }\end{array}$ & $(\%)$ \\
\hline 1985-1989 & José Sarney & 13 & 13,26 & $19.258,05$ & 16,35 & 945 & 18,75 \\
\hline 1990-1994 & $\begin{array}{l}\text { Fernando Collor/ } \\
\text { Itamar Franco }\end{array}$ & 12 & 12,24 & $12.999,13$ & 11,03 & 618 & 12,26 \\
\hline Total Geral & $\begin{array}{c}\text { Femando } \\
\text { Henrique Cardoso }\end{array}$ & 73 & 74,48 & $85.505,303$ & 72,60 & 3.476 & 68,98 \\
\hline & & 98 & 100 & 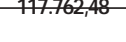 & 100 & 5.039 & 100 \\
\hline
\end{tabular}

Fonte: Incra (06/10/03). 
Em terceiro lugar, observa-se que no quadriênio de 1995/1998 as iniciativas tomadas para responder à demanda emergencial por terra, representadas pelos acampamentos, partiram exclusivamente do governo federal, pois o governo estadual sob o comando de Antônio Britto (PMDB) além de não ter demonstrado nenhum interesse em executar uma política fundiária, reprimiu sistematicamente as ocupações de terras, desconsiderando a legitimidade do MST enquanto um agente político relevante. ${ }^{12} \mathrm{~A}$ maior parte das aquisições de terras realizadas pelo Incra ocorreu na metade sul do RS, em função das seguintes razões: a) pela existência de terras de menor preço, quando comparadas às demais regiões; b) pelo aumento da oferta de terras ao Incra, em função da crise da agropecuária e da indisposição dos proprietários em possuírem imóveis rurais vizinhos aos assentamentos; c) pelo deslocamento das ações de pressão do MST sobre a metade sul, reconhecida por seus integrantes como uma região de latifúndios improdutivos. ${ }^{13}$

U m quarto aspecto determinante daquela conjuntura foi a nomeação de Jânio Guedes da Silveira, um funcionário de carreira da Emater/RS que possuía um posicionamento favorável ao avanço da política de assentamentos no Estado. Tal posicionamento, no entanto, era distinto das propostas preconizadas pelo MST e seus aliados, pois não concebia a possibilidade de realização de uma reforma agrária ampla e massiva no RS. ${ }^{14}$ Esta postura política foi importante no estabelecimento de uma relação de di-

12 Asúnicas ações realizadas pelo governo estadual no âmbito fundiário foram: a) a compra de duas áreas para a implantação de assentamentos, que somente foram efetivadas no governo O lívio Dutra; b) a criação de um Grupo de Trabalho para analisar a questão indígena; c) 0 lançamento do programa de crédito fundiário Minha Terra, no final do seu mandato (DA ROS, 2006a).

13 Depoimentos de Flávio Santana Xavier (Incra/RS), Carlos Antonio Dai Prá (Incra/RS), Mário Lill (MST/RS) e Nestor Hein (Farsul).

14 Segundo o seu depoimento: "Há espaço para a reforma agrária, mas não é como se fala nas estatísticas. (...) Pelos parâmetros legais vigentes, o campo para as desapropriações no RS é limitado. Agora, se olharmos pelo lado da concentração fundiária, da questão política, há condições para avançar" (Entrevista ao autor). 
álogo político entre o Incra e o M ST, bem como no enfrentamento político à reação exercida pelos grandes proprietários fundiários às vistorias.

O conjunto destes acontecimentos oportunizou a criação de um ambiente favorável à expansão dos assentamentos no RS, pesando decisivamente na emergência do movimento "vistoria zero", conforme será visto na sequência.

\section{O movimento "vistoria zero" como reação do patronato rural às políticas de assentamentos}

Para entendermos as razões que levaram os proprietários rurais de Bagé a se mobilizarem contra a realização das vistorias do Incra, é preciso considerar que a sua principal entidade de representação no Estado, a Farsul, sempre se opôs a realização de uma reforma agrária, combatendo politicamente os seus defensores. Desde os primeiros anos de existência a Farsul revelou uma presença política dominante, sobretudo ao posicionarse imediatamente próxima ao poder do Estado, constituindo-se na sua característica indissociável. Por um lado, a entidade é oficialmente a representante política e sindical dos grandes proprietários e por outro, atua como interlocutor do Estado nas políticas agrícolas e agrárias estaduais, fornecendo quadros especializados para atuar junto ao setor agrícola ${ }^{15}$ (HEINZ, 1991, p. 221-222).

No que se refere à questão agrária, a Farsul sempre se fez presente nos momentos em que o debate sobre o tema se intensificou em nível

15 Contudo, a influência da Farsul é maior em nível estadual, pois a entidade não detém uma capacidade de intervenção direta sobre as decisões na política econômica que afetam o meio rural, as quais se encontram objetivadas nas instâncias nacionais de poder. N estes casos a sua influência é exercida de maneira indireta e subordinada, mediante a intermediação dos seus pleitos pela Confederação Nacional da Agricultura (CNA), ou ainda, através do governo do Estado e dos representantes políticos regionais na Câmara dos Deputados e no Senado da República (HEINZ, 1991, p. 223). 
nacional e estadual. A primeira participação ocorreu nos anos 1960, quando buscou disputar os rumos das políticas agrárias, e na medida em que as mobilizações camponesas se intensificaram com o surgimento do Movimento dos Agricultores Sem Terra (Master), a entidade assumiu um posicionamento mais firme contra a reforma agrária. Nesta época foram registradas as primeiras ações coletivas unificadas do patronato rural em contraposição aos movimentos de luta por terra, mediante a realização de concentrações de proprietários, publicação de documentos e intervenções na imprensa estadual. Posteriormente, com o advento do golpe-civil militar de 1964 e o desbaratamento das forças pró-reforma agrária, a Farsul passou a se integrar mais fortemente ao setor agrícola em processo de modernização, ampliando e diversificando a sua base social para os produtores de arroz e soja do RS (HEINZE, 1991, p. 44-53).

A segunda participação da Farsul no debate da questão agrária ocorreu durante o período de transição do regime militar à "Nova República", quando o novo governo apresentou a sua proposta de PNRA no IV Congresso da Contag. Nesse momento, a entidade se integrou às demais organizações de representação do patronato rural no combate político e ideológico ao PNRA, inviabilizando a sua implementação através das pressões exercidas sobre as instâncias governamentais. Porém, o avanço das ocupações no campo protagonizadas pelo recém criado MST, acrescidas do temor de que estas conquistassem o apoio massivo da sociedade civil, contribuiu para o surgimento de uma "crise de representação no setor patronal"16 (HEINZE, 1991; RAMO S, 1995; BRU NO, 2005).

Tal fato possibilitou a emergência de novas formas de organização política, primeiramente objetivadas na criação de vários grupos de defesa às propriedades e, posteriormente na criação de uma organização de ca-

16 A crise de representação surgiu pela fragilidade, em nível de representação de classe, das organizações já existentes, diante da ameaça de uma reforma agrária, e também pela sua perda de influência sobre às instâncias estatais em face da redução na concessão de privilégios no âmbito das políticas agrícolas, ocorrida no início dosanos 1980, em razão da crise provocada pela dívida externa (RAM OS, 1995, p. 179-180). 
ráter nacional, a União Democrática Ruralista (UDR) ${ }^{17}$ (BRUNO, 2005). Essa nova entidade renovou as estratégias de luta política, construindo uma nova identidade social e política: a de "produtor rural", visando com isso aproximar-se dos sentidos urbanos atribuídos aos "empresários" e distanciar-se do antigo rótulo de "latifundiários" e "improdutivos" atribuídos por seus antagonistas (HEINZE, 1991, p. 214-215).

A atuação da UDR centrou-se num primeiro momento na contraposição àsocupações e na construção de uma identidade que unificasse os produtores rurais diante da ameaça de uma reforma agrária, movimentando-se por fora dos canais de representação oficiais. Num segundo momento, a atuação da UDR concentrou-se em solidificar a sua posição como organização representativa, agindo mais no campo jurídico mediante o oferecimento de assessorias aos produtores e também na forma de "lobby" junto à Assembléia Nacional Constituinte (RAM O S, 1995, p. 180). Tal movimentação foi decisiva na aprovação de preceitos constitucionais extremamente restritivos à aplicação de uma política de reforma agrária ampla e massiva, particularmente no que se refere à impossibilidade de desapropriação das terras produtivas, independentemente da sua dimensão.

Passado o período de intensificação dos debates em torno do PNRA e na ANC, a UDR foi sendo paulatinamente desativada em diversos estados do país e a representação do patronato rural voltou a ser feita pelas antigas entidades oficiais. Assim sendo, a Farsul passou a ocupar novamente um lugar de destaque na defesa dos interesses dos grandes proprietários, posicionando-se contrária à nova onda de ocupações de terras ocorridas nos anos 1990 e às iniciativas do governo federal em atender as pressões

17 As novas formas de atuação política incluíam ações diretas de enfrentamento aos acampamentos mediante a realização de leilões para arrecadação de fundos para as campanhas contra a reforma agrária, a constituição de grupos armados (milícias) para defender as propriedades, a concentração de produtores em vigília junto às propriedades ocupadas, a realização de atos públicos, caravanas, etc. 
dos movimentos por terra. N esta direção a entidade argumenta que a reforma agrária é uma medida "inútil" e "desnecessária" ao desenvolvimento do país, razão pela qual passou a condenar a expansão dos assentamentos nos anos recentes. E, quando o Incra passou a implantá-los em maior escala, as críticas dos representantes da Farsul concentraram-se em dois aspectos principais. 0 primeiro deles está relacionado a uma suposta "inadequação dos índices de produtividade à realidade estadual", o que faz com que a entidade seja contrária às propostas que visam atualizá-los para cima, especialmente no que se refere aos índices de lotação pecuária. ${ }^{18} 0$ segundo diz respeito aos procedimentos adotados pelo Incra nos processos de vistorias, considerados pela Farsul como processos "viciados", decorrente da falta de uma "atitude de independência" por parte da autarquia federal .19

Estas duas críticas se constituíram na justificativa política das primeiras manifestações dos proprietários rurais filiados ao sindicato rural de Bagé contra a realização das vistorias. Isto porque os integrantes do patronato rural gaúcho passaram a perceber que a continuidade das vistorias possibilitava a implantação de assentamentos nas regiões de grandes latifúndios, contribuindo para o processo de expansão de novos núcleos, mediante as compras e as desapropriações negociadas efetuadas pelo Incra ${ }^{20}$. Segundo Gedeão Pereira (Farsul/RS):

Nós sabemos que sempre que há um assentamento numa determinada região - e isso aconteceu nos

18 Cumpre registrar que os índices de produtividade atualmente em vigor foram estabelecidos com base nos dados do Censo Agropecuário do IBGE de 1975. De tal modo que uma das principais reivindicações dos movimentos sociais do campo favoráveis à execução da reforma agrária tem sido a sua atualização, a fim de adequá-los aos progressos científicos e tecnológicos ocorridos na agropecuária brasileira.

19 Depoimento de Gedeão Pereira Silveira (Farsul/RS).

20 Esta constatação é ratificada pelo depoimento de Flávio Santana Xavier (Incra/RS): “O mercado de terras para a reforma agrária, isto é, o mecanismo de compra e venda, só funciona quando conjugado à desapropriação feita pelo Incra. 0 mercado de terras não vem para 0 INCRA, ele vem quase que obrigado. Q uem oferecia terras para o Incra? Em $90 \%$ dos casos 
municípios de Hulha Negra e Candiota - se estabelece um efeito dominó, de acordo com o qual as propriedades começam a cair porque não conseguem conviver. 0 exemplo mais recente disso foi a ida da [Fazenda] Ana Paula para o U ruguai. U ma grande propriedade modelo que não conseguiu conviver com a presença dos assentamentos em função do alto nível de roubo e abjeato. Ela chegou a perder num ano mais de mil cabeças de gado por abjeato. Esta é uma prática dos assentamentos do MST: o alto nível de desorganização social, eu diria até de apodrecimento do tecido social produzido pelo pessoal do MST, porque eles são ociosos, eles não produzem, eles não têm eficiência, não trabalham, vivem sustentados pelo Estado e prejudicam aqueles que estão trabalhando. E ameaçam quem trabalha, pois há inúmeros exemplos na região da Campanha, notadamente naquela região de Hulha Negra e Candiota. Uma vez que as propriedades começaram a cair por ficarem lindeiras [no limite, ou vizinhas] com alguns assentamentos do MST, automaticamente só havia um comprador para elas, o próprio Incra, que as destinava de novo para o MST. Então chegamosa um nível insuportável. O sprodutores rurais, tendo conhecimento desse tipo de atitude, se rebelaram, até porque não há na região gente que viva com dinheiro de outro bolso, lá as pessoas vivem da atividade rural, vivem da terra que têm. Ou se perde a terra que tem - e aí se perde a vida, se

\footnotetext{
eram terras limítrofes aos assentamentos. Q ual era a nossa estratégia? O Incra fazia uma cabeça de ponte numa área não reformada e desapropriava um grande latifúndio improdutivo. Isso foi feito em Bagé, onde foram desapropriadas três grandes fazendas: Fundo, M adrugada e Jaguarão. Houve uma batalha judicial, o Incra ganhou e a desapropriação aconteceu. O s vizinhos, por preconceito e uma série de circunstâncias, não querem ser vizinhos de sem terra, a pior ofensa para um fazendeiro é ser vizinho de sem terra. Então eles começam a vender, mas ninguém quer comprar. Qual é a lógica do mercado? O Estado só compra terra se houver desapropriações" (Entrevista ao autor).
} 
perde a dignidade e se vira um sem terra -, ou se luta por ela. O que aconteceu em 1998 naquela região foram produtores rurais lutando desesperadamente pela sua sobrevivência, pelo seu quinhão, por aquilo que foi conquistado por eles e pelos seus antepassados (Entrevista ao autor).

0 depoimento acima expressa a oposição dos integrantes do patronato rural em relação à presença dos assentamentos nas regiões de latifúndios pastoris, os quais são encarados como ameaças à "boa convivência" nestes locais, sinalizando a sua intolerância a qualquer possibilidade de redistribuição da propriedade da terra. Desse modo, o acionamento de uma nova forma de ação coletiva, o movimento "vistoria zero" pode ser interpretado como uma tentativa de manter a sua posição de dominância no campo dos conflitos agrários, corroborando com as análises já realizadas por H einze (1991) e Ramos (1995) nas quais afirmam que o processo de construção de uma identidade de classe se fortalece nos momentos de ameaça às posições ocupadas. Segundo Ramos (1995, p. 198), “(...) Apesar de vários fatores serem responsáveis pela constituição de uma identidade comum, a propriedade da terra consiste no aspecto central deste processo, visto ser um elemento imprescindível para a reprodução dos próprios agentes".

Sob esta ótica, a ação coletiva não só foi justificada pelo patronato rural, como foi acompanhada de um discurso que visava desqualificar os trabalhadores rurais e suas organizações de representação estigmatizandoos socialmente, mediante a atribuição dos rótulos de "ladrões", "ociosos", "improdutivos", cuja sobrevivência "depende da sustentação do Estado", representando assim, uma séria ameaça "àqueles que trabalham" ${ }^{21}$. Tal

21 A utilização de argumentos de desqualificação dos trabalhadores rurais e suas organizações por parte das entidades do patronato rural não se constituem numa prática nova, pois são recorrentemente acionadas nos momentos em que o monopólio da propriedade da terra é posto em causa ou ameaçado. 0 trabalho de Bruno (2005) também apresenta evidências nesta direção, ao mapear os argumentos e posições das organizações patronais em sua luta política 
discurso reativou as percepções de classe já incorporadas ao nível do habitu ${ }^{22}$ dos porta-vozes do movimento de que a propriedade da terra se constitui num direito absoluto, "naturalmente" herdado e adquirido pelo trabalho, do qual emanaram alguns valores sociais da sociedade brasileira, entre os quais a "audácia", a "bravura" e o "destemor" para enfrentar a "adversidade" (BRUNO, 2005, p. 285).

Por essa razão, a autoidentificação do patronato rural como os legítimos detentores da propriedade, bem como a estigmatização impingida aos seus antagonistas, constitui-se numa estratégia de distinção acionada no âmbito das lutas simbólicas travadas no interior do campo dos conflitos agrários, cuja finalidade última é preservar a sua posição de dominância no espaço social. Neste sentido, o movimento "vistoria zero" se constituiu em mais um momento de aproximação e construção de um sentido de unidade entre aqueles agentes que ocupam posições próximas no espaço social, razão pela qual tendem a formar uma "classe provável", ou seja, um grupo mobilizado para a luta, que partilha de objetivos comuns e que

contra a implementação do PNRA, em 1985, destacando que quanto mais próximas estas estavam das cadeias agroindustriais, mais forte era a desqualificação impingida aos trabalhadores. Para a autora esta desqualificação está intimamente relacionada à reprodução da "ideologia da competência", travestida de uma forma sutil que a sociedade contemporânea inventou para legitimar a discriminação social e a dominação política de classe. Segundo a autora: “(...) U ma ideologia que separa, na sociedade, aqueles que teriam naturalmente o direito a decisão e ao poder, porque os privilégios de classe Ihes garantem a posse de conhecimentos técnicocientíficos, e aqueles que, por sua condição de classe, despojados do direito, teriam naturalmente o dever de serem meros executantes de tarefas e ordens emanadas dos que sabem" (Bruno, 2005, p. 289).

22 Segundo Bourdieu o conceito de habitusbusca enfatizar a dimensão de um passado adquirido, podendo ser definido como: “(...) um sistema de disposições duráveis, estruturas estruturadas predispostas a funcionarem como estruturas estruturantes, isto é, como princípio que gera e estrutura as práticas e as representações que podem ser objetivamente "regulamentadas" e "reguladas" sem que por isso sejam o produto de obediência das regras, objetivamente adaptadas a um fim, sem que se tenha necessidade da projeção consciente deste fim ou do domínio das operações para atingi-lo, mas sendo, ao mesmo tempo, coletivamente orquestradas sem terem o produto da ação organizadora de um maestro". In: BO URDIEU, Pierre. Esquise d'une théorie de la pratique. Genéve, Lib. Droz, 1972, p.175, Apud: O rtiz (1983: p. 15). 
ao mesmo tempo está em oposição a outro grupo ou classe ${ }^{23}$ (BO URDIEU, 2002, p. 136).

As primeiras manifestações dos grandes proprietários fundiários de Bagé contra a realização das vistorias e em favor da revisão dosíndices de lotação pecuária ocorreram no mês de março de 1998. 0 estopim desse processo foi a deflagração de uma operação de recadastramento de imóveis rurais pelo Incra, na qual estavam programadas a realização de visitas em 370 imóveis com área superior a 420 hectares. 0 recadastramento de imóveis era um programa que vinha sendo realizado desde julho de 1997 e tinha dois objetivos básicos: a) fazer um levantamento das famílias atendidas pela reforma agrária e que ainda permaneciam nos assentamentos; b) realizar um mapeamento completo das áreas produtivas ou não, identificando os imóveis passíveis de desapropriação. A operação contou com uma equipe de 22 funcionários, integrada por agrônomos, técnicos de cadastro e de topografia. Esse procedimento começou a ser executado em 1973, sendo realizado em todo o país de cinco em cinco anos (Zero Hora, 18/09/98). Tratava-se, portanto, de operação rotineira, na qual a autarquia federal estava apenas cumprindo a sua obrigação constitucional de aferição e fiscalização do cumprimento da função social da propriedade fundiária.

As primeiras manifestações contrárias a essa operação tiveram início no dia 04 de março de 1998, quando um grupo de 200 proprietários rurais fechou uma rua no centro da cidade de Bagé em frente ao hotel Fenícia, onde estavam hospedados os funcionários do Incra. 0 protesto foi organizado pelo Sindicato Rural de Bagé e culminou com a entrega de

23 Segundo Bourdieu: "Não se passa da "classe-no-papel" à classe "real" a não ser por um trabalho político de mobilização: a classe real, se é que alguma vez ela existiu "realmente", é apenas uma classe realizada, isto é mobilizada, resultado da luta de classificações como luta propriamente simbólica (e política) para impor uma visão do mundo social ou, melhor, uma maneira de construí-la, na percepção e na realidade, e de construir as classes segundo as quais ele pode ser recortado" (BOURDIEU, 1996, p. 26). 
um documento pelo seu presidente, na época, Gedeão Pereira Silveira, ao coordenador do Incra na região, Pedro Zilli, no qual era solicitada a suspensão imediata das vistorias, além de tecer severas críticas aos critérios adotados pela autarquia federal nas suas inspeções: "São índices descabidos e desconectados de quaisquer parâmetros reais no que tange a lotação de animais no campo" 24 (Zero H ora, 04/03/1998).

Posteriormente, os protestos evoluíram para ações coletivas de bloqueio à entrada dos funcionários do Incra nos imóveis rurais com visitas programadas, as quais tiveram início no dia 08 de abril de 1998, na localidade de Joca Tavares (Zero Hora, 09/04/98; Correio do Povo, 09/04/98). A realização das barreiras se estendeu até 0 dia 28 de agosto do mesmo ano, quando 0 governo estadual, o Incra e o M inistério da agricultura entraram em um acordo para suspender as vistorias no Estado, ao mesmo tempo em que anunciavam a aquisição de imóveis rurais mediante a realização de um leilão de terras (Zero Hora, 28/08/98). As ações lideradas pelo Sindicato Rural de Bagé contaram com a concentração de centenas de produtores nas entradas das fazendas, além de veículos e animais de montaria e de produtores vindos de outras regiões do Estado, do país e até de países vizinhos, como o U ruguai. Segundo o depoimento de Gedeão Pereira Silveira (Farsul/RS):

O Incra tentou fazer no município de Bagé aquilo que havia feito no Pontal do Paranapanema, ou seja, deslocou toda uma equipe, alugou dois andares de um hotel em Bagé e tentou fazer uma varredura através de vistorias. Nessa época o produtor rural - e foi a primeira reação que houve no Brasil contra a reforma agrária, da maneira como ela estava sendo colocada pelo Estado brasileiro - se levantou contra essas co-

24 As primeiras contestações aos índices de produtividade adotados pelo Incra foram apresentadas ao final de um encontro realizado em Santa Maria no dia 16/08/97. Posteriormente, os produtores de 12 municípios decidiram não assinar as notificações para as vistorias (Zero H ora, 22/04/98). 
locações e, realmente, foi uma movimentação tão intensa que se denominou na época de "vistoria zero". O u seja, os produtores trancaram as figuras do Incra, trancaram as vistorias no município de Bagé e isso foi quase uma revolução no campo, fomentando bastante a unidade do produtor rural neste estado contra esse tipo de ação governamental. Tanto assim que, a partir desse momento, a reforma agrária praticamente não mais vingou no estado do RS através da desapropriação de imóveis rurais (Entrevista ao autor, 17/11/2004).

O depoimento acima chama a atenção para a ambiguidade mantida na relação dos agentes do patronato rural em relação ao Estado, já apontada no estudo de Ramos (1995, p. 160), pois, por um lado, o Estado é visto como um entrave à sua reprodução como classe, dada a ameaça real de perda de suas posições mediante a efetivação da reforma agrária. Por outro lado, o Estado é visto como necessário à reprodução destes agentes, principalmente no que se refere à necessidade da sua intervenção no âmbito das políticas agrícolas. ${ }^{25}$ Neste caso, a "varredura" feita pelo Incra representou uma ameaça concreta à perda da posição de parte dos grandes proprietários fundiários, contribuindo para a construção de uma unidade entre agentes até então dispersos, opostos ao Estado, que sob estas circunstâncias específicas passou a ser considerado como um "inimigo" a ser combatido sem tréguas.

Para dar continuidade às ações de vistorias naquele período a equipe do Incra teve que entrar na justiça e obter liminares que garantissem o acesso dos seus funcionários nas propriedades, as quais não foram suficientes

25 Neste sentido, convém não esquecer que a influência exercida pelas organizações de representação política do patronato rural junto às instâncias do Estado ao longo da história, em particular durante o ciclo de modernização da agricultura ocorrido ao longo das décadas de 1960 e 1970, tem garantido a sua reprodução enquanto classe, contribuindo para preservar a sua posição de dominância no campo dos conflitos agrários. No período atual este processo se manifesta nas frequentes renegociações da dívida agrícola e nas pressões pela liberação de verbas governamentais para o financiamento do autodenominado "agronegócio". 
para impedir a montagem de novas barreiras pelos produtores rurais (Zero Hora, 15/04/98). A intensificação do movimento "vistoria zero" motivou a realização de uma audiência pública na Comissão de Agricultura e Política Rural da Câmara dos Deputados, objetivando discutir a questão da revisão dos índices de produtividade. Paralelamente, o presidente do Incra assinou a portaria n. 170, criando uma comissão especial para reavaliar os índices de lotação pecuária das terras, num prazo de 30 dias (Zero Hora, 23/04/98).

A comissão de estudo foi instalada no dia 20 de maio de 1998, sendo integrada pelos seguintes componentes: 1) Eduardo Freire, diretor de cadastramento do Incra; 2) Gilberto Bampi, técnico do Incra; 3) José O távio Neto Gonçalves, pesquisador da Embrapa/CPPSul (Centro de Pesquisas de Pecuária da região Sul); 4) José Mário de O liveira Freitas, técnico da Fepagro; 5) Felisberto Antônio Rosa Barros, funcionário da SAA/RS; 6) José Fernando Piva Lobato, professor do Departamento de Zootecnia da UFRGS; 7) H umberto Sorio Júnior, professor de zootecnia da UPF (Sorio Jr, 2001, p. 48). A formação dessa comissão, no entanto, não foi suficiente para impedir que os produtores rurais de Bagé dessem continuidade à realização de barreiras para obstruir a entrada dos técnicos do Incra, uma vez que estes exigiam ainda a suspensão das vistorias durante o período previsto para a definição dos novos índices (Zero Hora, 24/04/98).

O s trabalhos da comissão ocorreram em 11 reuniões, nas quais foram debatidas entre os seus integrantes três propostas de índices de lotação pecuária. ${ }^{26} \mathrm{~A}$ primeira delas foi defendida pelos representantes da Embrapa, da UFRGS, da SAA/RS e da Fepagro, na qual estava prevista a

26 Não analisaremos aqui em detalhe a luta política travada no interior da comissão, bem como quais foram os argumentos técnicos esgrimidos para legitimar uma ou outra proposta. Concentrar-nos-emos apenas em apresentar quais foram os principais desdobramentos dos resultados do trabalho da comissão sobre a continuidade dos processos de vistoria e das desapropriações por interesse social para fins de reforma agrária no RS. Sobre as principais polêmicas no interior da comissão especial consultar o trabalho de Sorio Jr. (2001). 
redução dosíndices de lotação pecuária que vinham sendo utilizados pelo Incra, baseando-se no argumento de que os resultados das pesquisas realizadas no Estado haviam demonstrado que num "sistema de pastoreio contínuo", 27 o aumento da carga animal traria sérios prejuízos à produtividade da pecuária. Segundo a matéria publicada no jornal Zero Hora:

A idéia é simples: um menor número de animais por hectare assegura alimentação suficiente ao rebanho para o abate de um novilho jovem e, como consequência, a produção de carne de melhor qualidade. (...) 0 professor do Departamento de Zootecnia da UFRGS José Fernando Piva Lobato explica por quê: - Quanto mais se adapta a carga animal às pastagens nativas, que variam de acordo com o solo, melhor os índices de repetição de prenhez e o aumento do ganho de peso. Lobato ainda diz que o excesso de carga conduz à fome dos animais e ao desaparecimento de espécies presentes no campo nativo (Zero Hora, 20/06/98).

A aproximação dessa proposta com os interesses dos pecuaristas gaúchos e da Farsul é flagrante, tanto é que esse mesmo professor da UFRGS e o representante da Embrapa/CPPSul na comissão especial, já tinham participado como co-autores da elaboração de um livro editado pela Comissão de Assuntos Fundiários dessa entidade, em julho de 1997, sob o seguinte título: Índices de lotação pecuária para o Rio Grande do Sul (SO RIO $J R, 2001$, p. 48). Tal fato contribui para pôr em causa qualquer argumento que invoque uma suposta isenção desses integrantes na referida comissão especial, uma vez que travestidos de argumentos "técnicos" e da chancela

27 Segundo Sorio Jr: "Este implica adaptar a capacidade de carga ao crescimento da pastagem. Como a capacidade de carga em qualquer estabelecimento tende a ser conservadora, as áreas submetidas a pastoreio contínuo tendem a ser sobrepastoreadas durante o inverno e princípios de primavera e subpastoreadas em fins de primavera, princípios de verão e parte do outono" (SO RIO JR, 2001, p. 20). 
legitimadora de instituições de pesquisa "idôneas" e "renomadas", assumiam uma postura conservadora no que se refere à definição de critérios para o cumprimento da função social da propriedade e, se fossem levados em consideração, sepultaria em definitivo a continuidade das políticas de assentamentos no RS baseadas nas desapropriações.

A segunda proposta foi defendida pelo professor Humberto Sorio Júnior da UPF e se baseava no argumento de que era possível aumentar a capacidade de lotação dos campos nativos, desde que se modificasse 0 seu sistema de exploração, uma vez que, na sua visão, a forma extensiva não era a mais adequada para incrementar a produção e a taxa de desfrute do rebanho gaúcho. ${ }^{28}$ Para tanto, o professor da U PF defendia a adoção de um novo sistema de exploração baseado no pastoreio rotativo, mais conhecido como Sistema Voisin, que consiste na subdivisão dos campos em parcelas menores, onde o pastoreio dos animais é alternado em períodos suficientemente curtos para permitir o rebrote das plantas e evitar 0 seu esgotamento. Assim, seria possível não só elevar a carga de lotação dos campos, como também melhorar a produtividade da pecuária gaúcha, aumentando o seu rebanho e a sua taxa de desfrute (SO RIO JR, 2001).

Como se vê, a proposta de Sorio Jr. não se resumia apenas a uma simples elevação dos índices de lotação pecuária, uma vez que apontava para a necessidade de modernizar os métodos de exploração da pecuária enraizados secularmente na região da Campanha Gaúcha. Embora o discurso da necessidade da modernização da pecuária seja recorrente no RS, cabe destacar que nem mesmo a introdução de novas técnicas de manejo do rebanho, ou mesmo a melhoria genética do plantel foram suficientes

28 A taxa de desfrute é a relação existente entre o efetivo total do rebanho e o número de cabeças abatidas. Atualmente serve como indicativo do grau de evolução da atividade, pois quanto mais alta for a taxa de desfrute mais evoluída tende a ser a pecuária. No RS, a taxa de desfrute no ano de 1989 era de 17,3\% e, em 1998, passou para 19,4\%. Esse pequeno crescimento está muito aquém das taxas de desfrute observadas na Argentina (23\%), na Austrália (30\%) e nos Estados Unidos (37\%) (SO RIO JR, 2001, p.78). 
para suplantar o pastoreio contínuo, pois as modernizações ocorridas na pecuária gaúcha sempre tiveram um caráter restringido (COSTA, 1988; PESAVENTO, 1994). Assim, não causa estranheza que qualquer proposta de revisão dosíndices para cima dosatualmente utilizados pelo Incra, seja combatida ferozmente, já que isso implicaria pôr em causa a atual estrutura fundiária que sustenta a manutenção de uma pecuária com baixos níveis de desenvolvimento, quando comparada com outros países do mundo.

A terceira proposta previa a manutenção dosíndices de produtividade que vinham sendo utilizados pelo Incra nas suas vistorias. Entretanto, no momento de se posicionarem na discussão, os técnicos do instituto que integravam os trabalhos da comissão acabaram se dividindo, o que serviu para fortalecer politicamente a primeira proposta e enfraquecer a segunda e a terceira propostas (Zero Hora, 19/06/98). O depoimento de um dos entrevistados desta pesquisa indica que, entre as possíveis razões que contribuíram para que a proposta defendida pela maioria dos integrantes da comissão especial hegemonizasse o debate político, deve-se, principalmente, a debilidade teórica dos técnicos do Incra e à estigmatização política do representante da UPF. Segundo Flávio Santana Xavier (Incra/RS):

A única pessoa que fez o debate ideológico foi o Humberto Sorio Júnior, um ex-companheiro de partido, de Passo Fundo. Mas ele é um cara estigmatizado - não tanto quanto eu - por ser também egresso do PCB , foi candidato e tal. Então ficou fácil para a direita manipular, taxando-o de comunista. (Entrevista ao autor)

Além disso, tanto o MST quanto as demais organizações de representação política da agricultura familiar do Estado, apesar de se manifestarem até hoje contrárias à revisão para baixo dos índices de lotação pecuária, não se envolveram no acompanhamento direto dos debates que se travaram no interior da comissão especial (Zero Hora, 07/05/98; Correio do Povo, 09/07/98). Segundo Mario Lill (MST/RS): 
Nós achamos que se trata de um falso debate. Segundo a Constituição, os índices devem ser corrigidos periodicamente, se não me engano de dez em dez anos. Então não se trata de discutir ou não, mas apenas aplicar a lei, como se aplica para desocupar uma área ocupada. Do ponto de vista político, nós achamos que o debate deve focalizar a fixação do limite de propriedade, é esse o debate central para o MST. A questão da produtividade é importante, mas não é central. (Entrevista ao autor, 14/09/2004)

Segundo o Artigo 11, da Lei n. 8.629: “(...) O s parâmetros, índices e indicadores que informam o conceito de produtividade serão ajustados, periodicamente, de modo a levar em conta o progresso científico e tecnológico da agricultura e o desenvolvimento regional, pelos M inistros de Estado do Desenvolvimento Agrário e da Agricultura e Abastecimento, ouvido o Conselho Nacional de Política Agrícola" (BRASIL, 2004, p. 383). Conforme fica explícito neste parágrafo, percebe-se que não se trata apenas de uma mera aplicação da Lei, como afirmou de maneira simplista o nosso entrevistado, mas, sim, de uma disputa política de grande envergadura, pois existe uma clara oposição de interesses entre o MDA e o Mapa, o que dificulta a construção de um consenso em favor de uma atualização dosíndices de produtividade. Enquanto o primeiro afirma-se como um espaço de manifestação dos atores políticos ligados à atualmente denominada "agricultura familiar" e à luta por "reforma agrária", o segundo tem sido historicamente o espaço de representação e de convergência dos interesses dos grandes proprietários fundiários e da agricultura capitalista de grande escala.

A participação do PT e do MST e das demais organizações rurais somente ocorreu de forma mais intensa durante a realização dos debates públicos, ocorridos a partir da finalização dos trabalhos da comissão especial. U ma das discussões mais emblemáticas ocorreu por ocasião da realização de uma audiência pública na prefeitura de Porto Alegre no dia 10 
de julho de 1998. Na ocasião, fizeram-se presentes os ruralistas (em número reduzido), os sem-terra vindos de um acampamento em Viamão (em 15 ônibus), técnicos de diversas instituições e o presidente do Incra, M ilton Seligmann. A polarização dos debates travados ao longo das quatro horas de audiência fez o presidente do Incra transferir o esperado anúncio dos novos índices para a semana seguinte, deixando escapar que a solução a ser apresentada pelo governo teria componentes "técnicos" e "políticos" (Zero Hora, 1/07/98; Correio do Povo, 11/07/98).

A solução para o impasse gerado pela revisão dos índices foi anunciada posteriormente pelo governo federal mediante a criação de uma Comissão Permanente de análise dos índices de produtividade. Esta comissão foi constituída por representantes dos ministérios da Agricultura e da Política Fundiária, ficando incumbida de analisar as propostas sugeridas pela comissão especial que analisara a situação do RS. O utra medida importante foi o anúncio de que o Incra passaria a considerar os novilhos precoces como adultos, passando de 0,37 Unidade Animal por hectares para 0,87 , atendendo uma antiga reivindicação dos pecuaristas gaúchos (Correio do Povo, 16/07/98). Inicialmente, o anúncio do governo serviu para acalmar os ânimos dos pecuaristas, no entanto, bastou o Incra dar prosseguimento às vistorias para que as barreiras fossem reativadas, sob 0 argumento de que o Instituto havia rompido com um suposto acordo verbal de suspensão das vistorias até que os novos índices fossem divulgados. A retomada das barreiras ocorreu no dia 14 de agosto e chegou a resultar na prisão do advogado do Sindicato Rural de Bagé (Correio do Povo 11/ 08/98; Zero Hora, 14/08/98).

A partir daí, as tensões entre o patronato rural gaúcho e o Incra atingiram o seu ponto máximo, sendo que a autarquia teve que solicitar reforço policial para auxiliar a entrada dos seus técnicos nas fazendas. A primeira tentativa de realizar vistoria sob acompanhamento policial também foi barrada, em face do baixo efetivo disponibilizado pela Brigada 
M ilitar (nove soldados) e pela Polícia Federal (três agentes), e pela presença massiva dos fazendeiros no local da vistoria (mais de mil ruralistas) (Zero Hora, 18/08/98; Correio do Povo, 18/08/98). Na segunda tentativa foi mobilizado um poderoso aparato policial que contou com um efetivo de 300 soldados da Brigada M ilitar, os quais conseguiram garantir a passagem dos técnicos e a realização da vistoria em uma fazenda no município de Bagé (Zero Hora, 26/08/98).

O fim dos protestos dos ruralistas somente ocorreu a partir do anúncio de um acordo firmado entre o governador, o ministro da agricultura e o Incra, no qual se previa a suspensão das vistorias no Estado, assim que estivessem concluídas aquelas que haviam sido determinadas pela justiça. A estratégia final consistia ainda, no anúncio durante a realização da Expointer na cidade de Esteio, da aquisição de terras pelo Incra mediante a modalidade de Leilão (Zero H ora, 28/08/98). O que, aliás, já vinha sendo considerado pelo governo federal como uma das alternativas de se evitar os conflitos e dar mais celeridade ao processo de reforma agrária no Estado (Zero Hora, 15/08/98).

0 acatamento do acordo feito em Brasília, por decisão dos ruralistas reunidos em assembléia no sindicato de Bagé, pôs um fim no movimento "vistoria zero" que durante mais de quatro meses polarizou as opiniões no RS (Zero Hora, 28/08/98). Na ocasião, o presidente do sindicato rural de Bagé anunciou que pretendia reunir na abertura da Expointer cerca de 10 mil produtores de todo o Estado, a fim de transformar o espaço num palco de protestos e debates (Zero Hora 28/08/98 e 05/09/98). Para completar esse cenário, alguns dias depois os jornais noticiariam a realização de cortes no orçamento do Incra em razão da crise econômica internacional, o que interrompeu na prática a continuidade do programa de recadastramento, obrigando o Incra a adiá-lo para o ano de 1999 (Zero Hora, 18/09/98; Folha de S. Paulo, 22/09/98).

A realização do movimento "vistoria zero" serviu para reforçar a tese em voga entre os gestores públicos do governo Cardoso de que as desa- 
propriações não eram o melhor caminho para os estados da região Sul e Sudeste, tanto é que se passou a estimular a adoção de mecanismos de obtenção de terras que privilegiassem a negociação, tais como, as compras, os leilões e o crédito fundiário, reforçando a opção pelo modelo de reforma agrária conduzida pelo mercado, cuja consolidação ocorreu no segundo mandato do governo Cardoso (Zero Hora, 02/09/98). ${ }^{29} \mathrm{Não}$ foi coincidência, portanto, que a primeira tentativa de Leilão de terras no país ocorreu no RS, no mês de novembro, tendo sido adiada para o mês de março de 1999, em razão dos vendedores de terras não terem apresentado a documentação no prazo (Zero Hora, 01/10/98).

A opção do governo FHC pelos leilões de terras e de alternativas de aquisição de imóveis rurais "menos conflituosos" sinalizou uma inflexão na política agrária federal, iniciada no final do primeiro mandato e consolidada no segundo, no sentido de retomar o controle da ação governamental evitando-se com isso de ficar "a reboque" das ações dos movimentos de luta por terra. Internamente o Incra nacional estava dividido entre uma posição que defendia o aperfeiçoamento do mecanismo da desapropriação via mudanças legislativas, e outra que apostava nos mecanismos de mercado, menos conflituosos, como as compras governamentais, o crédito fundiário e as "desapropriações amigáveis". Esta segunda visão partia de um diagnóstico negativo sobre a continuidade das desapropriações, manifestando também uma descrença na aprovação de mudanças legislativas para aperfeiçoar o instrumento da desapropriação no Congresso N acional. ${ }^{30}$

A predominância dessa segunda visão indicou uma convergência de interesses entre o governo Cardoso e o Banco M undial, pois ambos parti-

29 Segundo o depoimento do ministro Raul Jungmann, citado na matéria: "Se o leilão der certo, vamos revolucionar o processo de reforma agrária no Brasil. Vamos começar os leilões por aqui porque não me conformo que a meta do Estado seja assentar 1,5 mil família"s (Zero Hora, 02/09/98).

30 Depoimento de Jânio Guedes da Silveira (Incra/RS). 
Ihavam do diagnóstico de que a criação de mecanismos de obtenção de terras baseados no mercado contribuiriam para quebrar a conexão existente entre as ocupações de terras e as desapropriações, reduzindo assim, o grau de conflitividade social no campo. A expressão máxima desse ideário materializou-se nas experiências de crédito fundiário efetivadas sob o segundo mandato do governo Cardoso no âmbito dos programas o Banco da Terra e o Crédito Fundiário de Combate à Pobreza (PEREIRA, 2004). Em que pesem as tentativas tomadas pelo governo federal e pelo Incra na realização de leilões de terras na Bolsa de Mercadorias do RS, convém registrar que este fracassou rotundamente. ${ }^{31}$

Como resultado das ações desencadeadas no âmbito do movimento "vistoria zero", observou-se que no quadriênio seguinte a ação do Incra no RS ficou refém dos humores dos integrantes do patronato rural. Isto, porque, ao barrarem a continuidade das vistorias os grandes proprietários fundiários criaram um poderoso precedente político que passou a ser utilizado como moeda de troca com o Incra, nos momentos em que a pressão das ocupações organizadas pelo M ST exigia a sua retomada. A simples sinalização de que as vistorias poderiam ser realizadas passou a ser respondida com a ameaça de reativação do movimento "vistoria zero". Tal fato contribui para paralizar as ações de desapropriação do Incra, acarretando numa redução drástica do número de assentamentos criados no quadriênio de 1999/2002, conforme indica a tabela a seguir.

31 Leilão de terras na BMRS fracassa. Corretores alegam que preço de abertura oferecido pelo Incra não despertou interesse dos vendedores (Correio do Povo, 17/03/99). Segundo Paulo Emílio Barbosa (Incra/RS): "O primeiro leilão de terras realizado no Brasil foi aqui no Rio Grande do Sul, e os fazendeiros o boicotaram, não disponibilizando nenhuma área sequer. N ós saímos com uma frustração tremenda. 0 ministro Jungmann apostou todas as fichas naquele mecanismo, e não funcionou. Não sei se o governo conseguiu levar a termo tais leilões em outros estados do Brasil, mas se o fez, acho que também não deram em nada" (Entrevista ao autor). 
Tabela 3. Projetos de assentamentos implantados pelo Incra no RS entre 1995 e 2002.

\begin{tabular}{ccccc}
\hline Período & Presidente & $\begin{array}{c}\text { Numero de } \\
\text { Assentamentos }\end{array}$ & $\begin{array}{c}\text { Área total } \\
\text { em hectares }\end{array}$ & $\begin{array}{c}\text { Número } \\
\text { de famílias }\end{array}$ \\
\hline 1995-1998 & $\begin{array}{c}\text { Fernando H. } \\
\text { Cardoso }\end{array}$ & 73 & $85.505,303$ & 3.476 \\
$1999-2002$ & $\begin{array}{c}\text { Fernando H. } \\
\text { Cardoso }\end{array}$ & 27 & $23.347,00$ & 995 \\
\hline Total Geral & & $\mathbf{1 0 0}$ & $\mathbf{1 0 8 . 8 5 2 , 3 0 3}$ & $\mathbf{4 . 4 7 1}$ \\
\hline
\end{tabular}

Fonte: Incra (06/10/03).

Paralelamente, havia ainda uma indisposição do governo federal em confrontar os interesses do patronato rural, que se expressou na falta de respaldo político aos superintendentes regionais do Incra no RS para que estes dessem continuidade às vistorias. ${ }^{32}$ Tal postura era perfeitamente coerente às novas diretrizes de política agrária vigentes no segundo governo Cardoso, no qual a prioridade absoluta passou a ser o reforço dos mecanismos de obtenção de terras baseados no mercado (M EDEIROS, 2002; PEREIRA, 2004; MEDEIRO S; LEITE, 2004).

Assim sendo, a dinâmica da luta política em torno da questão agrária no segundo mandato de FHC seria marcada logo no seu início por uma forte oposição dos movimentos sociais e sindicais do campo ao Banco da Terra, sob o argumento de que este deslocava as funções do Estado, ameaçava o instrumento da desapropriação, relegava ao mercado a resolução do problema do acesso à terra e criava alternativas à pressão social organizada dos movimentos. ${ }^{33}$ As entidades patronais, por sua vez, apoiaram

32 Segundo o depoimento de Flávio Santana Xavier (Incra/RS): “De lá para cá as vistorias praticamente acabaram. Só aconteceram quando um superintendente queria ir embora. Foi o que aconteceu com o Jânio [Guedes da Silveira], por exemplo. 0 Jânio era o superintendente na época das primeiras vistorias em Bagé. Ele foi embora, depois reassumiu em 2000 e em 2002 decidiu fazer vistorias em São Gabriel. A Farsul fez as barreiras e o FHC o demitiu. Mas, do ponto de vista objetivo, de 1998 para cá praticamente não se fez mais vistorias" (Entrevista ao autor).

33 Convém registrar que a Fetag/RS, se constituiu numa das poucas exceções à regra, pois em virtude das pressões desencadeadas por seus sindicatos passou a defender a implantação do Banco da Terra no estado, contrariando as posições da Contag que em nível nacional se opunha ao programa (DA ROS, 2006b, p. 269). 
explicitamente o programa, principalmente por ele se pautar no respeito ao direito de propriedade e às regras de mercado e por procurar eliminar o conflito e as disputas fundiárias (M EDEIRO S, 2002, p. 82-89).

No Rio Grande do Sul, o Banco da Terra acabou se convertendo na principal modalidade de política fundiária executada pelo Ministério do Desenvolvimento Agrário. ${ }^{34}$ Entre as principais razões que explicam a sua abrangência, destacam-se: a) a demanda por terra existente nas regiões de minifúndio, provocadas pelos processos de sucessão hereditária que além de acentuarem a tendência de fragmentação das propriedades geram uma "população sobrante" com poucas alternativas de reprodução social e econômica; b) a montagem de uma estrutura descentralizada de gestão do programa, o que permitiu um maior controle dos sindicatos e das autoridades municipais na seleção dos beneficiários; c) a existência de uma conjuntura de baixa nos preços das terras, em virtude da paridade cambial e dos baixos preços das commodities no mercado internacional; d) a predominância de contratos individuais de compras de terras, o que favoreceu a concentração do Banco da Terra nas regiões de minifúndio; e) o uso do programa como instrumento de combate político ao MST e à reforma agrária baseada nas desapropriações, na medida em que o oferecimento de uma alternativa de acesso a terra que não passava pelos assentamentos disputou a base social potencial do MST, enfraquecendo o seu poder de pressão sobre o Estado (DA ROS, 2006b, p. 265-277).

Neste contexto, nem mesmo as expectativas criadas pela eleição do governo O lívio Dutra (PT), em 1998, claramente sintonizado com as rei-

34 Segundo os dados sistematizados por Pereira (2004, p. 229-230), no RS entre os anos de 2000 e 2002 o BT financiou 8.484 famílias a um custo total de $R \$ 173.829 .267,00$, o que representou $28,5 \%$ do total das famílias beneficiadas e $27,3 \%$ do total dos recursos investidos pelo programa em todo o país. Já na pesquisa realizada pelo $\operatorname{DESER}(2005$, p. 5) em alguns municípios gaúchos, consta que entre de 2000 e 2003 o BT financiou 10.136 contratos, totalizando R\$ 209,7 milhões. Apesar das divergências, ambas as fontes atestam a importância assumida pelo programa no Estado, cuja superioridade em relação ao programa oficial de reforma agrária é espantosa, uma vez que, entre 1999 e 2002, o Incra assentou apenas 995 famílias no Estado. 
vindicações do MST e seus aliados, foram suficientes para reverter a opção do governo federal pelos mecanismos de mercado. A sinalização de que em seu mandato seriam assentadas 10 mil famílias de agricultores sem terra e que os conflitos fundiários seriam tratados como "casos de política" e não de "polícia" criaram um ambiente favorável ao aumento da pressão social via ocupações de terras. Segundo os dados fornecidos pelo GRA/RS, no quadriênio de 1995/1999 foram registradas 22 ocupações de terra, reunindo um público total de 4.361 famílias $^{35}$. (DA ROS, 2006a) Contudo, a abrangência assumida pelo Banco da Terra acabou atuando como um "colchão amortecedor" do esperado aumento da pressão social por reforma agrária no RS, posto que este programa disputou a demanda por terra pela base, reduzindo a afluência dos sem-terra aos acampamentos do MST. Assim, constata-se que o movimento "vistoria zero" pesou decisivamente nas opções assumidas pelo governo Cardoso e nos resultados atingidos pela sua política fundiária.

\section{Considerações finais}

Ao longo deste artigo procuramos analisar o processo de constituição do movimento "vistoria zero", a fim de verificar os seus desdobramentos na contraposição à implementação das políticas de assentamentos no Rio Grande do Sul no quadriênio de 1999/2002. Para tanto, utilizamos como referencial analítico a noção de "campo dos conflitos agrários", a fim de entender as ações coletivas do patronato rural a partir de uma perspectiva

35 No quadriênio seguinte, este número saltou para 33 ocupações, reunindo um público de 5.725 famílias, correspondendo a um aumento percentual de $50 \%$ no número de ocupaçõese de $31,27 \%$ das famílias acampadas (Rio Grande do Sul, 2002).

36 Essa citação em matéria do jornal Zero Hora indica as dificuldades encontradas pelo Incra: "Visitamos 60 fazendas e fomos impedidos de trabalhar em 140 locais - diz o engenheiro agrônomo e coordenador operacional do instituto em Bagé, Pedro Zilli". In: Clima de guerra com o INCRA (Zero Hora, 05/07/98). 
mais ampla dos embates travados contra os seus antagonistas em torno da posse e uso da terra. Neste sentido postulamos que o movimento "vistoria zero" se constitui numa das reações possíveis desencadeadas pelo patronato rural frente às ameaças potenciais ou reais de alteração nas suas posições de poder, cuja principal força reside no monopólio da propriedade da terra. Tais ameaças são representadas pelas ações fundiárias desencadeadas pelo Estado no sentido de responder às ações de pressão dos movimentos sociais do campo em favor da reforma agrária.

Através desta análise foi possível constatar que esse movimento se singularizou por ter sido a primeira mobilização política, ocorrida no RS, a partir da liderança de um sindicato patronal para impedir a realização de vistorias pelo Incra, caracterizando-se por ser uma ação ilegal, uma vez que impossibilitou a autarquia federal de cumprir com a sua função constitucional de fiscalização do cumprimento da função social da propriedade fundiária. Tal ação colocou os ruralistas e a sua entidade de representação, a Farsul, em flagrante contradição com o seu discurso de defesa da "legalidade", rigorosamente cobrado dos governos estaduais a cada ocupação realizada pelo MST.

A eclosão deste movimento foi diretamente influenciada pelo encadeamento de um conjunto de acontecimentos no quadriênio de 1995/ 1998, que não só recolocaram o tema da reforma agrária no centro da pauta política nacional, como contribuíram para impulsionar a ação do Incra na implantação de um número expressivo de assentamentos no RS, avançando sobre as regiões de pecuária extensiva na metade sul. Essa expansão territorial dos assentamentos foi prontamente combatida pelo patronato rural e suas organizações de representação política, as quais passaram a criticar os índices de produtividade utilizad os pelo Incra, além de questionar os processos de vistorias, por considerarem estes "viciados". Contudo, o que definiu o início da reação contra as vistorias foi a percep- 
ção de que a sua continuidade possibilitaria a implantação de assentamentos nas regiões de grande propriedade, abrindo caminho para a expansão de novos núcleos.

Do ponto de vista político, a realização de barreiras na entrada das propriedades rurais para impedir a entrada dos técnicos do Incra, pode ser equiparada às ocupações de terras realizadas pelo MST, uma vez que também se constituem num tipo de ação direta. A diferença entre ambas reside nos objetivos finais preconizados pelas ações. As ocupações se caracterizam como uma ação que visa tornar público o não cumprimento da função social de um determinado imóvel rural, pressionando o Estado a realizar a sua desapropriação e, numa perspectiva mais ampla, se constituem numa das principais estratégias de luta política pela realização de uma reforma agrária. As barreiras dos ruralistas, por sua vez, visam impedir a aferição do cumprimento da função social da propriedade rural pelo Incra, convertendo-se numa estratégia de luta que bloqueia a continuidade das desapropriações e, numa perspectiva mais ampla, constituiu-se numa estratégia nitidamente contrareformista.

N este sentido, maior vitória política alcançada pelo movimento "vistoria zero" foi a de ter imposto a suspensão das vistoriais por tempo indeterminado no Estado, ao mesmo tempo em que promoveu um questionamento dos índices de produtividade utilizados pelo Incra. ${ }^{36}$ Além disso, as pressões dos ruralistas levaram o governo a acatar a proposta de formação de uma comissão especial para revisar os índices de lotação pecuária, a qual foi majoritariamente composta por técnicose pesquisadores que contribuíram para chancelar e legitimar politicamente uma proposta de índices coerente com as posições defendidas pelo patronato rural e a Farsul.

Ao questionarem a legitimidade dos atuais índices de produtividade, os integrantes do patronato rural gaúcho se concentraram sobre o principal critério utilizado pelo Estado para fazer cumprir a função social da propriedade fundiária. Em que pesem as evidentes limitações presentes 
no atual ordenamento jurídico legal para a execução de uma reforma agrária, pode-se dizer que o critério da improdutividade mensurado a partir dos índices de produtividade, bem ou mal, ainda tem possibilitado a continuidade das desapropriações e a implantação de novos assentamentos. Caso fossem vencedoras na sua tentativa de rebaixar os índices de lotação pecuária, as organizações de representação política do patronato rural gaúcho teriam conseguido, numa só cartada, deslegitimar a ação do Estado e dos movimentos sociais. Eis a razão pela qual este evento apresentou uma importância crucial no entendimento da luta política em torno da questão agrária gaúcha nos anos 1990, pois permitiu a criação de um precedente político que será acionado todas as vezes que as ocupações de terras e as ações do Incra, extrapolarem os limites aceitos pelas organizações do patronato rural.

O smovimentos sociais do campo e as forças de esquerda, em especial o PT, ao não participarem diretamente do debate em torno da definição de uma nova proposta de índices na comissão especial, abriram espaço para a legitimação da proposta defendida pelo patronato rural. Com isso, perderam uma grande oportunidade para pôr em causa com argumentos "técnicos" esgrimidos por pesquisadores com posições próximas à Farsul, deixando as propostas apresentadas tanto pelos representantes do Incra quanto da UPF órfãs de um necessário apoio político para a sua legitimação.

Como resultado constatou-se que o movimento "vistoria zero" contribuiu para paralizar as ações de desapropriação do Incra no RS, acarretando numa redução drástica do número de assentamentos implantados no quadriênio de 1999/2002. Além disso, contribuiu para reforçar a tese do governo federal de que no RS o melhor caminho seria apostar nos mecanismos de obtenção de terras que privilegiassem a negociação em detrimento do conflito. Nesta direção, as compras, os leilões e o programa de crédito fundiário como o Banco da Terra se consolidaram como as principais ações da política agrária do segundo governo FHC. A eleição de 
um governo estadual sintonizado com as reivindicações do MST e seus aliados, apesar de ter gerado expectativas acerca da ampliação do acesso a terra, contribuindo para aumentar o número de famílias acampadas no RS, não foi suficiente para reverter a orientação adotada pelo governo federal.

\section{The "zero inspection" movement and the rural employers' opposition to the settlement policies in the state of Rio Grande do Sul, Brazil}

\section{Abstract}

This article analyzes the formation process of the rural employers' resistance movement against the inspection of rural properties conducted by Instituto Nacional de Colonização e Reforma Agrária - INCRA (National Institute of Colonization and Land Reform) in the state of Rio Grande do Sul, in order to understand the ramifications of this action as opposed to the implementation of settlement policies from 1999 to 2002. This movement broke out in M arch 1998, led by big landowners from the Rural Union of the Municipality of Bagé, who called it "zero inspection". This unprecedented movement soon spread all over the State, an addition to the rural employers' opposition to the process of expropriation for land reform purposes. Throughout the article, the author maintains that the blockade the rural employers imposed on the inspections is directly responsible for the drastic decrease in the number of families settled by INCRA in the years between 1999 and 2002, which is in accordance with the second administration of President Fernando Henrique Cardoso and its support for market-assisted land reform.

Keywords: Land reform. Settlements policies. Rural employers. Inspection. Marketassisted land reform. 


\section{Referências}

BENETTI, Maria Domingues. Reestruturação do agronegócio no Brasil e no Rio Grande do Sul nos anos 90: concentração, centralização e desnacionalização do capital. In: FLIGENSPAN, Flávio Benevett (coord.). A economia gaúcha e reestruturação nos anos 90. Porto Alegre: FEE, 2000. p. 63-116. BENETTI, M aria Domingues. Rio Grande do Sul: estratégias empresariais nos agronegócios, no período de 1990, e questões emergentes. Indicadores Econômicos FEE, Porto Alegre: FEE. v. 25, n. 3, 1997. p. 169-209.

BOU RDIEU, P. 0 poder simbólico. Rio de Janeiro: Bertrand Brasil, 2002.

BOU RDIEU, Pierre. Razões práticas: sobre a teoria da ação social. Campinas, São Paulo: Papirus, 1996.

BRASIL. Constituição da República Federativa do Brasil. Rio de Janeiro: Roma Victor, 2003.

BRASIL. Estatuto da Terra - O bra coletiva de autoria da Editora Saraiva com a colaboração de Antonio Luiz de Toledo Pinto, Márcia Cristina Vaz dos Santos Windt e Lívia Céspedes. São Paulo: Saraiva, 2004.

BRU NO, Regina Ângela Landin. Nova República: a violência patronal como prática de classe. Sociologias, Porto Alegre, ano 5, n. 10, jul/dez 2003. p. 284-310.

CALDART, R. S. Pedagogia do Movimento Sem Terra: escola é mais do que escola. Petrópolis: Vozes, 2000.

CAM ARGO, Aspásia de Alcântara. A questão agrária: crise de poder e reformas de base (1930-1964). In: FAU STO, Bóris (dir.). História geral da civilização brasileira. Tomo III. O Brasil republicano. v. 3. Sociedade e Política (1930-1964). São Paulo: Difel, 1986, p. 121-294.

CARVALHO FILHO, José Juliano de. Política agrária do governo FHC: desenvolvimento rural e a nova reforma agrária. In: LEITE, Sérgio (org.) Políticas públicas e agricultura no Brasil. Porto Alegre: Editora da U niversidade/U FRGS, 2001.

COSTA, R. H. da. RS: Latifúndio e identidade regional. Porto Alegre: Mercado Aberto, 1988.

DA ROS, César Augusto. A implementação do Banco da Terra no Rio Grande do Sul: uma leitura política. In: SAUER, Sérgio ; PEREIRA, João M árcio M endes. Capturando a terra: Banco Mundial, políticas fundiárias neoliberais e reforma agrária de mercado. São Paulo: Expressão Popular, 2006b. p. 259-284.

DA RO S, César Augusto. As políticas agrárias durante o governo O lívio D utra e os embates sociais em torno da questão agrária gaúcha (1999-2002). Tese (de doutorado) Rio de Janeiro: CPD A/U FRRJ, 2006a . 
DESER - Departamento de Estudos Sócio-Econômicos Rurais. Capacidade de pagamento do crédito fundiário no sul do Brasil: Análise a partir do programa o Banco da Terra - Relatório de pesquisa. Curitiba: 2005.

FERN ANDES, B. M . A formação do MST no Brasil. Petrópolis: Vozes, 2000.

FIO RI, José Luís. Para um diagnóstico da modernização brasileira. In: FIO RI, J. L; MEDEIROS, C. Polarização mundial e crescimento. Petrópolis: Rio de Janeiro: Vozes, 2001.

FO RSTER, Germano José. A privatização das terras rurais. Barueri, SP: Manole, 2003.

GASQ U ES, José Garcia ; CO N CEIÇÃO, Júnia Cristina P.R. A demanda de terra para a reforma agrária no Brasil. In: Reforma agrária e desenvolvimento sustentável. Brasília: M inistério do Desenvolvimento Agrário, 2000. p. 85-109.

GOM ES DA SILVA, José. A reforma agrária brasileira na virada do milênio. São Paulo: Campinas: ABRA, 1996.

HEINZ, Fávio M adureira. Representação política e formação de classe: as organizações da burguesia agrária gaúcha na oposição a reforma agrária, 19851988. Dissertação (de Mestrado). Porto Alegre: UFRGS, 1991 -

HEREDIA, B; MEDEIROS, L; PALMEIRA, M; CINTRÃO, R; LEITE, S. Análise dos impactos regionais da reforma agrária no Brasil. Estudos Sociedade e Agricultura, Rio de Janeiro, n. 18, abr de 2002. p. 173-180.

LEITE, Sérgio Pereira et al, (Coord.) Impactos dos assentamentos: um estudo sobre o meio rural brasileiro. São Paulo: Editora Unesp, 2004.

MARTINS, José de Souza. 0 cativeiro da terra. São Paulo: LECH - Livraria Editora Ciências Humanas, 1981.

MARTINS, J. S. Reforma agrária: o impossível diálogo. São Paulo: Edusp, 2000. MEDEIROS, L. Movimentos sociais, disputas políticas e reforma agrária de mercado no Brasil. Rio de Janeiro: CPD A/U FRRJ e U N RISD, 2002.

MEDEIRO S, Leonilde Sérvolo ; LEITE, Sérgio Pereira. M archas e contramarchas na política agrária no governo Fernando Henrique Cardoso (1995-2002). In: INESC (org.) A era FHC e o governo Lula: Transição? Braślia: Instituto de Estudos Socioeconômicos, 2004. Disponível em <www.inesc.org.br> .

MEDEIRO S, Leonilde Servolo de. Reforma agrária: Concepções, controvérsias e questões. Fórum Alternativas para a agricultura brasileira - Rede Interamericana Agricultura e Democracia (Cadernos Temáticos). Rio de Janeiro: 1994.

MEDEIRO S, Leonilde Servolo de. Reforma agrária: Concepções, controvérsias e questões. Fórum Alternativas para a agricultura brasileira - Rede Interamericana Agricultura e Democracia (Cadernos Temáticos). Rio de janeiro: 1994. 
NAVARRO, Zander. Democracia, cidadania e representação: os movimentos sociais rurais no estado do Rio Grande do Sul, Brasil, 1978-1990. In: NAVARRO, Zander (O rg.). Política, protesto e cidadania no campo: as lutas sociais dos colonos e trabalhadores rurais no Rio Grande do Sul. Porto Alegre: Editora da U niversidade/U FRGS, 1996.

O RTIZ, Renato (org.). A procura de uma sociologia da prática. In: Pierre Bourdieu: Sociologia. São Paulo: Atica, 1983. p. 07-29.

PEREIRA, João M árcio M endes. 0 modelo de reforma agrária do Banco Mundial em questão: 0 debate internacional e o caso brasileiro. Teoria, luta política e balanço de resultados. Dissertação (de mestrado). Rio de Janeiro: Curso de PósGraduação em Desenvolvimento Agricultura e Sociedade/U FRRJ - 2004.

PESAVENTO, Sandra Jatahy. História do Rio Grande do Sul. 70 ed. Porto Alegre: Mercado Aberto. 1994.

RAM OS, M arília Pata. 0 novo e o velho ruralismo no Rio Grande do Sul: um estudo sobre os integrantes da UDR. Santa Cruz do Sul: Editora U NISC, 1995.

RIO GRANDE DO SUL - GABINETE DA REFO RMA AGRÁRIA. Números gerais da reforma agrária e organograma. Porto Alegre: 2002.

SANTOS, José Vicente Tavares dos. Crítica da sociologia rural e a construção de uma outra sociologia dos processos sociais agrários. Ciências Sociais Hoje, São Paulo, 1991. p. 13-51

SO RIO JÚ NIO R, Humberto. A ciência do atraso: índices de lotação pecuária no Rio Grande do Sul. Passo Fundo: UPF, 2001.

Entrevistas concedidas ao autor

1. Carlos Antônio Daí Pra - Engenheiro Agrônomo, Ex- Coordenador da Divisão de Aquisição de Terras da Superintendência Regional do Incra/RS, concedida em 01/04/2005.

2. Flávio Santana Xavier - Procurador do Incra, Ex-Assessor de Assuntos Jurídicos do DRA, concedida em 30/08/2004.

3. Gedeão Pereira Silveira - Ex-Presidente do Sindicato e Associação Rural de Bagé e Presidente da Comissão de Assuntos Fundiários da Farsul, concedida em 17/09/2004.

4. Jânio Guedes da Silveira - Ex-Superintendente Regional do Instituto Nacional de Colonização e Reforma Agrária (Incra), concedida em 09/09/2004.

5. Mário Lill - M embro da Direção Estadual do MST, concedida em 4/09/2004.

6. Nestor Hein - Presidente da Comissão de Assuntos Jurídicos da Federação da Agricultura do Rio Grande do Sul (Farsul), concedida em 08/09/2004. 
M atérias de jornais consultadas

Corte de recursos suspende vistorias. O Incra interrompe o cadastramento rural dentro de um plano de medidas para economizar 194 milhões. Zero Hora, Porto Alegre 18/09/98.

Produtores protestam contra inspeção do Incra em fazendas. Duzentos agricultores fecharam, com tratores, uma rua do Centro. Zero Hora, Porto Alegre, 04/03/1998.

O ito meses de protestos. Zero Hora, Porto Alegre 22/04/98.

Produtores bloqueiam estrada. Zero Hora, Porto Alegre, 09/04/98.

Ruralistas param técnicos do Incra. Correio do Povo, Porto Alegre, 09/04/98.

Acordo prevê a suspensão das vistorias. Governo federal confirma a aquisição de 30 mil hectares no Estado para conter os ânimos dos fazendeiros. Zero Hora, Porto Alegre, 28/08/98.

Produtores de Bagé desafiam a ordem judicial: pecuaristas fizeram nova barreira e impediram o acesso dos fiscais do Incra à fazenda de deveria ser vistoriada. Zero Hora, Porto Alegre 15/04/98.

Governo cede a pressões de produtores. Comissão especial terá 30 dias para reavaliar os índices de produtividade usados pelo Incra no Estado. Zero Hora, Porto Alegre 23/04/98.

Produtores rurais mantém barreiras, Zero Hora, Porto Alegre, 24/04/98.

Comissão propõe índices para a pecuária. Zero Hora, Porto Alegre 20/06/98.

Incra apresenta três propostas. Ó rgão fez reavaliação dos índices de lotação agrária no estado. Zero Hora, Porto Alegre, 19/06/98.

MST contesta proposta feita por fazendeiros de Bagé. Zero Hora, Porto Alegre 07/05/98.

Fetag não aceita a redução dos índices. Correio do Povo, Porto Alegre, 09/07/98.

Sem-terra esquentam debate na Câmara. Zero Hora, Porto Alegre,1/07/98.

Lotação pecuária do RS em debate - Revisão dos índices foi analisada ontem na audiência pública. Correio do Povo, Porto Alegre, 11/07/98.

Governo mantém os índices de lotação pecuária. Correio do Povo, Porto Alegre, 16/07/98.

Barreira impede vistoria em Bagé. Correio do Povo, Porto Alegre, 11/08/98.

Advogado preso em confronto - produtores rurais tentam impedir vistorias de técnicos do Incra em Bagé. Zero Hora, Porto Alegre, 14/08/98.

Ruralistas barram fiscais do Incra e policiais. Zero Hora, Porto Alegre, 18/08/98. 
Incra não faz vistoria. Correio do Povo, Porto Alegre, 18/08/98.

Brigada garante vistoria de fazenda. Zero Hora, Porto Alegre, 26/08/98.

Acordo prevê a suspensão das vistorias. Governo federal confirma a aquisição de 30 mil hectares no estado par conter os ânimos dos fazendeiros gaúchos. Zero Hora, Porto Alegre, 28/08/98.

Incra pretende evitar novas desapropriações. Zero Hora, Porto Alegre, 15/08/98. Pecuaristas resolvem desmontar barreiras. Zero Hora, Porto Alegre, 28/08/98.

Ruralistas ampliam debates em Esteio. Produtores prometem se deslocar ao parque em Esteio no dia 04 de setembro, na inauguração oficial da Expointer. Zero Hora, Porto Alegre, 28/08/98.

Q uestão agrária dá o tom da feira. Solenidade oficial em Esteio teve a presença de 10 mil produtores rurais convidados pela Farsul. Zero Hora, Porto Alegre, 05/09/ 98.

Corte de Recursos suspende vistorias. O Incra interrompe o cadastramento rural dentro de um plano de medidas para economizar 194 milhões. Zero Hora, Porto Alegre, 18/09/98.

Corte atinge programa de recadastramento de terra. Folha de S. Paulo, São Paulo, 22/09/98.

Leilões de terra começam em dois meses. Zero Hora, Porto Alegre, 02/09/98.

Leilão de terras será em março. Zero Hora, Porto Alegre, 01/10/98.

Clima de guerra com o Incra. Zero Hora, Porto Alegre, 05/07/98.

Recebido: 14/08/2008 Aceite final: 25/08/2008 